\title{
PERCEPTIONS OF MALE PROFESSORS AND MALE STUDENTS TOWARDS GENDER EQUITY POLICIES AND PRACTICES IN A MEXICAN HIGHER EDUCATION SCIENCE AND ENGINEERING GRADUATE PROGRAM
}

\author{
A. Masinire \\ Curriculum Studies \\ University of Witwatersrand \\ Johannesburg, South Africa \\ e-mail: Alfred.Masinire@wits.ac.za / https://orcid.org/0000-0002-1329-8569
}

\section{E. Sanchez-Cruz}

School for Foreign Students

Universidad Veracruzana

Mexico

e-mail: esanche@alumni.uwo.ca

\section{ABSTRACT}

One of the critical indicators of a gender equal society is the proportional and balanced representation of male and female in all spheres of life. Within the higher education sector in Mexico, gender transformation and equality is measured through the proxy of increased access of female students in higher education. Such demographic changes are occurring as a response to feminist demands for gender equality. While we acknowledge the physical visibility of female academics and students in higher education, this has not been achieved without opposition from male defenders of the status quo. In this study we examine the perceptions of male students and male faculty with regards to the gender policies and their attitudes to the presence of more female students taking up Sciences and Engineering graduate programs. Focusing on the perspectives of men is crucial in gender issues since transformation which does not involving men will likely be opposed by men in defence of gender privileges. The findings reflect that male academics and students men were caught up in conflicting position of accepting the policies in principle but rejecting them in practice. This contradiction arose from deeply internalized and normalized gender stereotypes which deserve educational attention and pedagogical intervention. Officially, the gender policy has affirmed female access and participation in the Science and Engineering graduate program at NPI. However, cultural and institutional gender regimes have not yet aligned themselves to the new policy framework. The question remains as to whether men can change their perceptions about traditional gender roles and responsibilities in order to leverage gender equity and transformation for women justice. Despite literature that suggests that men should be partakers in the fight for gender equality, findings in this study have no affirmative answer to the question. 
Keywords: Gender Equity Policies, transformation, Higher Education Mexico

\section{INTRODUCTION}

\section{Authors' memoir: Reflecting on global gender policies a local context}

"In February 2011 my colleague and I were invited to Mexico at a Science and Engineering Graduate Program to share our knowledge about gender inequality in higher education. We were coming from Canada where we were both $\mathrm{PhD}$ graduate students. For three days we engaged in conversations about gender inequality with both staff and students. At times our conversations became so heated to a point where we felt gender equality would take a long time to be achieved. There was a sense in which our presence was viewed with suspicion as we were viewed as privileged for being associated with Canada, a developed first world. There were insinuations in many men's and even some women's talk that gender equality was a foreign idea from the West. The foreign gender ideas were understood as disrupting the cultural gender traditions of Mexico. We were viewed as emissaries of that toxic gender equality influence. If anything, I think our presence was met with a strong opposition and our original purpose was a total failure. As student activists of gender equality our experience here was frustrating."

We preface this article with our abortive visit to Mexico which in a number ways illustrates some key issues which we find significant in understanding gender equality. The first issue is the reception and understanding of international gender policies from the Global North by participants in a local context, particularly in the Global South. In our case gender equity policies in the Mexico are viewed as external impositions from the developed and privileged Global North. Such policies were understood as bearing very little to do with the urgent needs of the Global South, especially the esteemed cultural traditions. The second is the response of men to gender equality. As noted by Stromquist $(2015,113)$, "the gender concept has been recognised by many public institutions and yet it has not been taken up in any profound way in public governance and management, with the result that its full implication and complex manifestations are not receiving proper scrutiny". In a way, our experience exemplifies the contradictory intersection of global gender policies and local national realities. We were accepted in principle but our message of gender equality was highly suspect and resisted.

Gender inequality serves the interests of men in many societies. Indicators of gender inequality have been noted to include women's exclusion from participating in the economy, access to resources, assets and other forms of discrimination (Narayan et al. 2000). Radical feminist movements informed by the Women in Development (WID) perspective have adopted an antagonistic stance against men since they defined their suffering as resulting from men's benefits. Of particular concern in WID discourse is the absence how men are implicated in women's subordination. There is often a portrayal of men as the sole enemy, who are irresponsible and unabated authority (Cornwall 2007). WID discourse, thus, suggests men are 
irrelevant in all policies and interventions which seek to advance the interests of women.

Recent agitation and advocacy for gender equality now adopt a gender relations framework and thus argues that the struggle against gender inequality and injustice should involve men and women working together. To what extend are men cooperating in working with women to end gender inequality? Can we expect that men will peacefully relinquish their hold on power that comes with gender inequality? Connell (2005) has labelled men and boys as "gatekeepers" of the current unequal gender structures in society. The concept of "patriarchal dividends" coined by Connell (1995) helps to understand why most men are likely to resist granting of equal status to women. This article investigates the responses of male academic staff and male students to policies of gender equality in a male-dominated field of study at a Polytechnic University in Mexico. The purpose was to explore the perceptions and experiences of male students and male academics to the increased presence of female academics and female students in a previously male dominated science graduate programme. The study is significant because it offers a male perspective to the gender policies that are meant to uplift the status of women.

\section{THE PROBLEM AND QUESTIONS}

One of the critical indicators of a gender equal society is the proportional gender representation of male and female in all spheres of life. Within the higher education sector in Mexico, gender transformation and equality is measured through the proxy of increased access of female students in higher education. In particular gender transformation and equality is expected in Science Engineering and Technology, fields of study which have enjoyed male monopoly. The field of Science and Engineering usually associated with Science Technology Engineering and Mathematics (STEM supporting) has been a preserve of male students and staff. A raft of policy guidelines have been legislated nationally and also internationally to ensure that a policy framework guide gender equalizing practices. While acknowledging the visibility of female students/academic in higher education and also the gains that have been achieved, this has not been achieved without opposition from male defenders of the status quo. Some men have fought to undermine the feminist gains, defending male privilege bestowed unto them as a result of patriarchy.

In this study we examine how gender equity policies have been operationalised in one Science department in a higher education in Mexico. Specifically, we were interested in the perspectives of male students and male faculty with regards to the gender policies and their attitudes to the presence of more female students taking up Sciences and Engineering graduate programs. The research questions we sort to answer were; what are the perceptions of male 
academic staff and male students regarding gender equity policies at the Polytechnic University of Mexico? Do male students and academic staff support the gender equity policies? How do they interact with female students in the male-dominated graduate program? Focusing on the perspectives of men is crucial in gender issues since any initiated policy change without involving men will likely suffer backlash politicking from defenders of male privileges.

\section{THE GLOBAL AND NATIONAL GENDER POLICY CONTEXT}

Gender inequality has gained the recognition of international organizations as a result of a long and intense work of women's organizations, feminist movements, academic communities and non-governmental organizations. The importance it has gained is reflected in the international and national public policy agenda as a component of development strategy and as a frame to recognize gender inequalities that require policy attention. One of the notable international gathering was the 1995 Beijing fourth World Conference on Women which called the world to work towards addressing current inequality in women's access to economic resources, productive life and also ensure support to institutional structures designed to promote the welfare of women (Razavi and Miller 1995).

Acknowledging gender as a framework which can be employed to evaluate the needs of women and men may generate policies which can establish goals required to satisfy needs, demands and interests to eradicate gender inequalities. It is interesting how policy regularities and similarities appear across countries and yet practical impact of these policies varies across contexts. This is mainly due to the fact that international agreements take part in international women's conferences spaces and in meetings of academic feminists (Tarrés 2006) and not in the actual spaces they are designed to function.

One of the most recognized international Conventions adopted by the United Nations (UN) General Assembly in 1979 was the Elimination of All Forms of Discrimination against Women (CEDAW). CEDAW is often noted as an international agreement which accepts and defend the rights of women. By accepting the Convention, countries commit themselves to address the gender inequality of women in all spheres of life. In the last decade of the 20th century, the promotion of public policy initiatives addressing gender inequality was adopted in Conventions, International Treaties and World Conferences as noted in the Beijing Platform of Action above. The Millennium Development Goals established the advocacy of gender equality and the women empowerment. In the meantime, the academy began to work for the design of policies geared to support women empowerment. More recently the United Nations (2009) makes the declaration to: 
- Use gender equality in their legal system, thus, abolish of visible forms of discrimination against women.

- Put in place structures which would facilitate and guarantee the protection of women.

- Put in place interventions which would eliminate all forms of gender discrimination.

Regionally, the Economic Commission for Latin America and the Caribbean (ECLAC) organized Conferences for Women in 1977, 2007, 2010, 2013 and 2016 "to review the regional and sub-regional situation with regard to women's autonomy and rights, to put forward recommendations on public policies on gender equality, to undertake periodic assessments of the activities carried out in fulfilment of regional and international agreements and to serve as a forum for discussion on gender equality" (ECLAC n.d., 1). In addition, the Inter-American Convention was also established to protect violence against women (Convention of Belem do Para) in 1994 promoted policies to protect women and defend their human rights in order to reduce all types of violence.

At national level Mexico has ratified the international, regional and sub-regional conventions and put in place action plans to champion gender equality and eliminate poverty among women as well as girls. In a way, the inclusion and recognition of women rights require government commitment to reduce poverty, promotion of an active role of women in politics, reduction of violence and equal access to education.

In 1996 the National Program of Women was established, later known as the National Institute for Women (Inmujeres). Inmujeres promote interventions designed to ensure that women's rights are easily accessible and can benefit from development in a context that frames gender equity and equality among men and women (Inmujeres 2018).

Moreover, Mexico has also promoted the rights of women within its own legislation and public policies with the promulgation of General Law of the Access of Women to a Life Free of Violence in 2007. This law establishes juridical guidelines that the State has to follow and identifies different types of violence like, psychological, physical, economic, educative, and includes sexual harassment. Since then, institutions of higher education have established, along with other public institutions (for instance health services and security services) gender offices within their structures of management.

The gender policy framework (both global and local) culminated in a host of interventions and programs implemented to increase women's livelihoods. As noted by Yeboah, Serbeh and Bembir (2015) most of programmes designed to curb gender inequality have remained onesided with disproportionate focus on women and as opposed men. We argue that excluding men 
in the fight against gender inequality is rather unfortunate as this would render the project of gender equality unsustainable. Rather analysis of gender should adopt a balanced perspective which considers men not only as the cause of gender inequality but also an indispensable aspect the solution (Greig, Kimmel and Lang 2000).

\section{ALLIES OR FOES: MEN IN THE FIGHT AGAINST GENDER INEQUALITY}

WID and GAD approaches to transforming gender relations have conceived men and women in unitary and homogeneous terms. Men were depicted as the problem and essentially the barrier in the way to gender transformation. These approaches have led to what Cornwall and White (2000) have termed "the missing half of gender" or what Chant and Gutmann (2002) have called "male blindness". In the struggle against gender inequality, men occupy a contradictory position. Can men be trusted, when they have historically and currently enjoyed the benefits of inequality? Why would men want change in the current arrangement which benefits them? Connell (1995) postulation of a theory of gender relations is useful and significant in pushing forward any gender reform program or intervention. Gender is a highly relational concept and understanding how both men and women are positioned in this relationship is crucial for any interventions that seek to bring about gender justice and equality. After all, it is not all about gender but how it relates to other structures of society. Therefore, we need to attend to issues of class, race, location and other social categories if we are to move beyond a bi-polar conception of gender as a problem between men against women. The concept of intersectionality complicates gender as a category and allows us to envisage femininities and masculinities not only as definitions of womanhood and manhood but as possibilities that both gender may appropriate and exercise. Thus any attempt to address gender inequality should simultaneously attend to men and women instead of positioning men as the cause of women's disadvantage. Some radical feminist activists have been sceptical of mutually allying with men in their fight for gender justice as they convince that their suffering is directly commensurate with men's privileges. A victim-perpetrator; women-men binary has guided the compensatory designed intervention programmes such as those propelled by WID and GAD discourse. More nuanced understanding of gender rejects essentialist depictions of women and men. Postcolonial theoretical insights from black feminists particularly from the third world has helped in illuminating the complexity of gender beyond the male-female bifurcation to include other social markers such as race, class, ethnicity and marital status (Mohanty 1988; 2003; Mohanty, Russo and Lourdes 1991). A more robust and useful perspective is proffered by Connell (1995) in his articulation of the concept of multiple masculinities and femininities which are related in often complex and contradictory ways. There is a hierarchy of 
masculinities, argues Connell with some hegemonic, some marginalized and subordinated, thus not all men benefit automatically by embodying a male body. Therefore, how men respond to gender policies cannot be described in unitary and predetermined terms. However, this should not override the fact that men as a group (consciously or unconsciously) benefit from the patriarchal order. There are inherent male privileges that accrue from the patriarchal dividend (Connell 1995). Feminists' struggles against gender inequality have encountered indifference, support and opposition from men. Nevertheless, there has been growing acknowledgement of the conceptual and practical paralysis of excluding men in gender and development programmes (Tripathy 2009; Yebouh et al. 2015; Chant and Gutmann 2002; Connell 2003). Connell (2003) argues that men are implicated in gender inequality and it is not difficult to change gender relations towards equality without taking on board all social actors. She goes further to give a number of pragmatic reasons why that is the case:

- The economic, political and cultural resources in existing patterns of gender inequality are controlled by men and reforms require resources to support the changes. Therefore, men who are in charge of the resources should be willing to give out their resources in order to support women's claims for justice.

- Gender relations are present in organizational practices, in religion and law discourse concepts and in are experienced in daily life of the people.

- Relations of gender are multi-dimensional, intersecting in all structures of social life including the economic, emotional, language and meaning.

While GAD and WID initiatives had a prefixed stance of excluding men in their reform agenda which has resulted in an automatic closure of men's participation, gender mainstreaming acknowledges the need for men' participation. Emerging research on masculinities is demonstrating that gender imbalance emerge from social definitions and construction of notions and identities of being a man. Therefore, gender equality can be achieved if men and boys embrace other ways of being men, which are different from traditionally accepted notions of manhood.

\section{WOMEN IN HIGHER EDUCATION IN MEXICO}

As far back as 1974 the national policy in Mexico was beginning to consider gender equality seriously. For example, the setting up of the National Program for Women that ensured that women had equal access and participate fully in education at all levels. As noted by Diario 
Oficial de la Federation, (2007) some policies in education, suggest the need to dismantle gender stereotypes. The General Policy for the Access of Women to life without Violence (Canada: Immigration and Refugee Board of Canada 2008) ensures that stereotypes in institutions of education documents are removed. For example, item 38 insist that programs should be set up to advocate and raise awareness of gender rights, including respect for women. These local directives to achieve gender equality align significantly with global dictates. United Nations Millennium Development Goal demanding for gender equality in education by 2015 was universally accepted, with nation states committing themselves to meeting nationally mandated targets.

Given the above national and international policy imperatives, Mexican women have better access into higher education when compared to the past. Despite the increased access to higher education it is still noted that a disproportionate number of women are still participating in those programmes deemed (Bustos Romero 2003). On the other hand, men continue to monopolise those programmes considered important in society. It can be argued that, gender imbalance continues to be a cause an unresolved issue particularly in how certain programme continue to perpetuate gender discrimination against women. Admittedly there is a huge change in the visibility of women in programmes previously dominated by men and conversely the presence of men in programmes previously dominated by women. However, there is still a glaring imbalance with respect to the management positions women hold and the respect they are given in those positions (Moss 2006). SEP (2003) notes that there were more male students admitted into higher education between 1990 and 2001 when compared to female students. However, when we aggregate these figures at specific sectors in higher education level, we see a decline in the gains made by women. At Masters and $\mathrm{PhD}$ level gender disparities persist (Bustos Romero 2003).

Regardless of a supporting gender friendly policy environment, the educational fortunes of women in higher education in Mexico lag behind that of their male counterparts. Sanchez (2003) notes that women struggle to enter and succeed in higher education because of two factors: 1) the patriarchal culture constantly reminds women that being passive, submissive caring for children are their feminine responsibilities; 2) During graduate studies female students endure the pressure of getting married and have a stable family thus they have to choose between getting married and further studies. A great deal of research has examined the experiences of women in education. As noted above a bulk of this research is quantitative in nature, concerned with the questions of how many women have gained access and in which programs? Some studies also document experiences of women in these programs but also reflect a female bias. Participants are usually women. This study is methodologically significant 
in that the participants are men. Both male staff and male students constitute the "gate-keepers" of an unequal gender structure which culturally and materially benefit them. If any change in gender relations has to happen it might depend on the extent to which these gate-keepers are willing open up to change. Consequently, accumulating knowledge concerning the perceptions of men to the presence of women in higher education becomes important.

\section{GENDER EQUITY POLICIES AND INTERVENTIONS AT THE NATIONAL POLYTECHNIC INSTITUTE (NPI) UNIVERSITY OF MEXICO}

This study was conducted at one higher education institution in Mexico which will be referred to as NPI. The NPI was made up of a diverse array programmes ranging from undergraduate, graduate and technical and research centres. This study focused particularly on the graduate school and specifically at the Science and Engineering program. Unlike the Humanities and Social Studies graduate program, the Science and Engineering program is historically and notoriously known for its exclusion of female students. Because of this antecedent, the Science and Engineering Graduate Program provided a fertile ground for understanding the impact of education related gender policies and ancillary interventions on the fortunes of women and girls.

The goal of NPI is to train professionals in the scarce skills of technology which are needed for national economic competitiveness and development in the global context. NPI offers prestigious programs which are highly competitive in terms of their admission criteria. However, in terms of gender representation there were few female students and staff than male (Estadistica Intitucional Trienio 2004-2006). Although there is an imbalance in terms of men versus women in the NPI, the pattern begins to show more women in institutions of higher learning. And yet we know very little about what men feel about the sudden visibility of women in these spaces. Do men accept women as equal partners in the science and engineering graduate program? How do men perceive the various instruments, policies and protocols designed to uplift the status of women in the Science and Engineering Graduate Program? Are men resistant to gender change? Have men changed their perceptions about women?

\section{MANIFESTATIONS OF GENDER (IN)EQUALITY AT NPI}

The NPI has instituted gender equity policies and interventions to support the achievement of equality. One of these measures includes the setting up of a gender office as a structural unit in 2012. The main objective of the gender office is to promote the law to curb violence against women. The unit is responsible for incorporating the gender perspective in the institution and to ensure that gender is not a cause of discrimination, inequality, violence and lack of 
opportunities in the development of the women and men in the academic and vocationaltechnical fields of the institute. The unit promotes campaigns, conferences, publications, policies, workshops and produces materials to help disseminate the discourse gender equality among its staff and students. The guiding objectives of the gender office were outlined as stipulated in the Que es el PIGPG, (n/d):

- Develop affirmative action to support staff through research programs

- To develop gender sensitive programs to shift the perspectives and lives of the NPI community.

- Establish links and cooperate with external organisations in designing policies that promote gender equity.

- To organise and support conferences and workshops that support gender equity

The activities of the unit can be accessed on the NPI website. Also visible is the violence poster which is physically observable on the major entrances to main buildings at NPI. The violence poster describes the various cases of gender violence. There is also a legal gender office which receives complaints on sexual harassment or violence against women. The gender unit offers guidelines on the steps to follow when one wants to file a complaint and may accompany the affected person to the legal department. The legal department is in charge investigating, convicting and punishing if it considers it appropriate. The above structures attest to the desire and resolve of NPI to address the plight of women at the institution. At the time of this study the director of NPI was female. Many participants considered the appointment a female director as a concrete illustration of NPI's commitment to gender equality.

\section{METHODOLOGY}

This study is developed from a major project that explored how gender equity policies were manifested in the experiences of female students at a Mexican University (Sanchez-Cruz 2012). Data was collected through interviews with students, professors and administrators based. In all 18 interviews were conducted. For this study we focus on data from male staff and male students. In all 3 students, 4 professors and 5 administrators were purposefully selected to participate in this study. The participants responded to open ended interviews and commented on various policies operating within the grogram and also how they interacted with women. 


\section{FINDINGS AND DISCUSSION}

As a signatory to many international statutes Mexico has put in place and implementation strategies to attain gender equality. Implementation and impact of these policies become real in the lives of students and staff. This study aimed to investigate the perceptions held by male professors and students on gender equity policies and practices in a male-dominated graduate program.

We structure our presentation and discussion of findings into two sections. Firstly, we consider men's perceptions of the material manifestations of gender equity policies. Secondly, we focus on the men's perceptions of the concrete experiences of women when these policies are operationalized into practice in the daily lives of women. We argue that gender equality becomes a reality at the intersection of policy pronouncement and the manner in which these policies are successfully implemented and become lived realities of female students and professors. We will also argue that men's perceptions of the gender equity policies should be congruent with their perceptions of the applications of these policies in the academic and professional lives of female students and professors. The perceptions of male students and staff were complex and conflicting but in the main they were opposed to gender equity, reflecting a mismatch between understanding of policies and their application.

\section{PERCEPTIONS ON MANIFESTATIONS OF GENDER POLICIES}

\section{Access equity policies}

From interview data gender equity was perceived by participants as having equal chances to benefit all the services available at the institution. The participants perceived NPI as having achieved gender equality. Victor a Dean of one of the departments at NPI claimed that women had the same chances as me and could rise through the professional ladder up to the top.

Other participants also applauded the enabling policy environment at NPI which was reflected by equal opportunities provided to men and women in the institution. As gender equity was defined in terms of access, we probed further but where are the women? After further probing about the underrepresentation of women, male professors maintained female students had an equal chance as male students to compete for the available vacancies; everyone could apply and there was no discrimination. As Victor continued to defend gender equal access policy, he claimed that admission into each programme was based on merit rather than favouritism on the grounds of gender.

At NPI, a female was appointed as the general director of the institution and this was hailed as a signal demonstrating a significant progress towards gender equity (2009-2012). For 
the male staff having a female director as a concrete illustration of gender was moving towards equity. For example, Thomas Dean of one of the departments at NPI claimed that NPI was a leader in gender equity throughout Mexico because it had appointed a woman as director of its institution. No other higher education in Mexico had appointed a woman as a director. As a female director she was championing issues of gender equality in her institution.

Similar sentiments were encored by Jose an administrator, who remarked that NPI was far ahead of others in terms of equity because no other public university in Mexico was directed by a woman. However, Jose was quick to doubt the positive values of gender equity because as a woman she might be promote other women. Jose noted the likelihood of reserve gender discrimination (Sher 1975). He was anxious about a woman's appointment as a general director. Jose's sentiments above are clouded in a concern of reverse-discrimination. Equality is viewed by Jose as making gains for women at the expense of men. Equality involved removing men and replacing them with women. When women have taken over, where will men stand? The fact that women were gradually encroaching into usually reserved spaces for men was echoed by other male deans at NPI. At the same time, the male Deans were also suspicious of the abilities of women in the graduate program. Similarly, they apportioned blame on women for failing to take full advantage of the gender equity policies available within NPI.

At the level of policy symbolism as mandated at international and national levels we would accept Victor, Jose and Gerardo' s perception that women had equal opportunities as men to access graduate studies program at NPI. Equally we would also accept that female professors had equal chances as men to be employed at NPI. However, Victor and other men's perceptions reflect the dominant trope towards education access which is driven by WID advocacy and the attendant neo-liberal discourse. The neo-liberal thrust is guided by an erroneous assumption that as soon we open access, men and women have agency as individuals to pursue their academic goals, thus gender equity will be achieved. Kabeer (2001) has vehemently criticised WID as a liberal rubric because of its emphasise on the rational and autonomous individual who is homogenous across all societies. So we probe further why despite open and equal access women were still invisible? Our further probing suggests that gender equity should be explored beyond the surface of numerical representation because women who sneak through the first hurdle of access continue to endure discrimination by men. Our analysis of the equity policies moved from the symbolic manifestation to concrete experiences of the policies.

\section{The gender office: A women's office}

The gender office was established in 2009 at NPI. The gender office was viewed by participants 
as the main platform championing issues gender equity at the institution. They highlighted the activities done at the office to help fight against gender discrimination. Victor pointed out how information on gender made easily accessible throughout the institution via such channels as posters and pamphlets. There were also clear avenues if one had a grievance related to gender discrimination.

Victor's perception about the gender office is that it is a women's office established to address women's needs. Men have no direct role in the gender office and its activities. The same sentiments were conveyed by Arturo an Administrator as he said,

The gender office is mainly responsible for informing women whenever their rights were violated and what to do if they want to report an incident of violence. His responsibility as an administrator involved, Conveying information through emails and posters from the office to members of the university community.

The gender office was a physical manifestation depicting the progress in the gender equity initiatives. The participants also referred to other notable activities spearheaded by the office such as: distributing posters, emails and anti-violence and discrimination information. However, men did not seem to take full responsibility and commitment to their initiatives emanating from the gender offer. Thomas an administrator claimed that, "these initiatives were externally driven and disseminated through top-down structure, despite the fact that there was genuine need was from the bottom".

A key discussion point was also the violence poster which was generated from the Gender Office and posted on entrances to many of the buildings at the NPI. According (Sanchez-Cruz 2012) the violence post was perhaps the most vivid and visible gender equity symbol. Participants viewed the violence poster as a palpable object symbolising gender equity. The violence poster listed in order of gravity gender discrimination practices, from a scale of 0 to 10 with corresponding punishments to offenders of each crime. There was also information on the appropriate recourse which the victims should pursue in order to get justice.

Male graduate students also viewed the violence poster as a critical feature in helping to comprehend gender violence and discrimination in the institution. Daniel of the students attributed all his knowledge of gender equity to the information he acquired from the violence post. Daniel explained that the violence poster listed all forms of violence ranging from verbal, physical touching, improper jokes, rape as well as murder.

It is interesting to note that men seem to position themselves in a particular way in relation to the Gender Office and its activities to promote equality and fair treatment of women. They viewed the office as a women's office established to address mainly violence against women, the office advised women about their rights and urged them to report any incidents of violence 
and discrimination. They have no direct involvement in achieving the mission of the office besides conveying information passed from above to women at lower levels. Thus while the opportunity to access the programme was available to women professors and female graduate students and policies were in place to protect them, it required a positive perception by male professors and male graduate students to actually bring about gender equity.

\section{Paternity leave: A double benefit for men}

The participants also viewed parental leave as an aspect of gender equality. At the IPN (n.d.) fathers were granted 10 days of paternity leave in 2010 . They were proud of this and urged other institutions to follow their example. As Pedro commented neighbouring institutions were supposed to follow the example set at IPN (n.d.).

Pedro's understanding of gender equity is fundamentally skewed. For him women have always benefited from maternity leave so equality should imply men going on paternity leave as well. Paternity leave is good but it already adds to a host of other advantages that men enjoy in the gender structure. In the case of the elevation of a woman to a position of Director we have noted how most men were obnoxious and seem to suggest that the woman director would favour other women. Thus, men perceived positively gender policies which were favourable to them and were not so comfortable with gender policies that seem to promote and advance the interests of women.

Petro's view of maternity leave below helps to illustrate the slope-sidedness of men's understanding of gender equity. While he acknowledged need for both parents to take leave he seems to suggest that women do not necessary need 90 days of leave during pregnancy and after giving birth. He narrated incidences of female professors who report for work unto to a point they would give birth, thus forgoing their 90 days maternity leave. Many of these women go directly from work to the hospital on the day they give birth.

Instead of explaining rationally why women persist at work until they give birth, Petro thinks women do not need the days at all and that if they decide to go on leave, the 90 days will not impact their academic productivity. Research has shown that women go on unpaid maternity leave if they have more than 2 pregnancies in a row. That is why pregnant women continue to work until they give birth. The case of female graduate students was even more disheartening, illustrating how gender equity policies were far from making any meaningful impact on the learning experiences of female students. The new gender equity initiatives were implemented in a stifling gender normative culture which was overridden by a neoliberal technical accountability mode of operation. Performance evaluation and closely monitored graduate funded programs also shaped men's understanding and commitment to gender equity. Female 
graduate students are advised by their male professors not to fall pregnant as this would jeopardise their chances of completing their studies on time.

\section{Maternity leave: Unequal conditions of female students}

Female students who had access to the Science and Engineering graduate programmes at NPI were discriminated against by male professors because of their gender. This was evident in the manner in which they were treated with respect to being pregnant and their right to maternity leave. In fact the whole funding mechanism and strict programme completion targets militated against females' capacity to pursue their studies. Alex, a male professor was reluctant to supervise female students because he was afraid that fall pregnant and this would affect their progress in their studies. He said, he usually advice his female students about the educational challenges of being pregnant whilst registered in the programme. According to Alex, being pregnant resulted in grave economic and academic consequences for the centre in terms of funding. As result it was imperative for the centre to admit and registered students complete on time.

From the above comment pregnancy in the course of study is not accepted because it retards the female student's progress towards completing her studies on record time. Failing to progress due to pregnancy also affect the recruitment of new students.

Another dimension of female students being pregnant was offered Gerardo professor who attributed pregnancy to a strategy employed by female students when they discover that the studies were difficult.

Gerardo further suggested that female students get pregnant when they have difficulties with a subject. His attitude towards pregnant students suggests that he was biased against women and their capacity to study as well as being with maternal responsibilities. While Alex and Gerardo above maintained that becoming pregnant were a problem for the institution in terms completion rates and funding, Igor another male professor presented pregnancy as a matter of human rights. For Igor female professors and female students had different rights governing pregnancy. It was only the female professor who could be granted a year away from duty if they become pregnant, however with no pay. On the other hand female students had no such provision in the event that they become pregnant.

The men at IPN (n.d.) recognised gender equity as the men's rights for paternal leave. However, the same men would not support reduction of workload when female professors became pregnant. In terms out academic productivity pregnant women were still expected to deliver the same outputs as their male counterparts. A similar bias was expressed by Alex and Gerardo towards female students who, according to these professors, become pregnancy as 
excuse for failing to satisfy the requirements of their study programmes.

In many ways the participants were caught up in a dual bind of accepting the policies in principle but rejecting them in action. This contradiction arose from deeply internalised and normalised gender regimes which require pedagogical intervention. Even though the participants seemed to accept that gender rights were legitimate, they could not disrupt normative gender scripts embodied in their daily practices due to culturally entrenched assumptions in their workplace. The participants did not perceive as problematic the toxic assumptions which they upheld

\section{DISCUSSIONS AND CONCLUSION}

Officially, the gender policy has affirmed female access and participation in the Science and Engineering graduate programme at NPI. However, cultural and institutional gender regimes have not yet aligned themselves to the new policy framework. For example, the funding patterns are strict and did not accommodate female students who fall pregnant.

Sanchez-Cruz and Cruz-Cortes (2015) found out that female students in a graduate programme at IPN (n.d.) were discriminated and abused on the basis of their gender by male staff and students. While their analysis was based on female students' experiences, one does not get a sense as to why this was happening, especially what were the men doing? The contribution of men in gender equity initiatives should not be viewed only as the cause of the inequality but equally as significant acts in providing the solution (Greig et al. 2000). As pointed out by Connell $(2003,4)$ men and boys are intricately implicated in issues of gender inequality and it is not possible to equalise gender orders without involving them. This study precisely adds the dimension of men and their implication in the fight for and against gender justice and equality in a higher educational context.

Although there were significant changes reflecting representative gender equality in higher education as evidenced by the appointment of a female director, enrolment of female students, gender office, workshops and posters; maternity leave and funding of female students, male professors and students' perceptions about these changes indicated discomfort and resistance to change in gender relations. NPI illustrates the collusion of global policy imperatives and local construction of gender policies and practices. Thus, the implementation and realisation of gender equity policies was not propelled by local forces. These policies were derived externally from outside Mexico with limited buy-in from the local context.

The context of NPI in general and the Science and Engineering programme in particular perceptions of male professors and students was shaped by external discourses in ways which materially impacted on educational and personal experiences of female students and female 
academics. NPI was caught up in a problem of the implementation of massive initiatives coming from outside, thus lost sight of the need to adjust their local culture and in instituting grassroots initiatives which would drive policies of gender equity and fight sexual violence and harassment.

As noted by Mohanty et al. (1991) international policy discourse of gender equity produce tensions at the local national level. With respect to NPI the local gender culture and the evaluation for accountability interacted in complex ways to shape the global gender equity policies in ways that robbed the female staff and students their equal rights to work and education.

The question remains as to how men should change their perceptions about gender roles and responsibilities in order to leverage gender equity and transformation for women justice. As this study has established, gender equity policies and initiatives did not produce substantive change for female students and academics. Policies designed to curb gender inequality thus could therefore understood as serving political symbolism (Rizvi and Lingard 2010) with very little (if any) positive material and practical consequences, leaving female students and academics subjected to a gender unfriendly and insensitive learning environment. Can men be entrusted with the role to attain gender equity? Despite literature that suggests that men should be partakers in the fight for gender equality, findings in this study have no affirmative answer to the question.

\section{REFERENCES}

Bustos Romero, O. 2003. Mujeres y educacion superior en Mexico: Recomposicion de la matricula universitaria a favour de las mujeres reperrcusiones educativas, economicas y sociales. http://www.scielo.org.mx/pdf/ries/v3n6/v3n6a1.pdf (Accessed 17 July 2011).

Canada: Immigration and Refugee Board of Canada. 2008. Mexico: Adoption of the General Law on Women's Access to a Life Free of Violence (Ley General de Accesso de las Mujeres a una Vida Libre de Violencia), its implementation regulations, and local implementation laws in the Federal District and the states of Mexico, Jalisco and Querétaro. MEX102833.FE https://www.refworld. org/docid/48a3028817.html (Accessed 10 June 2019).

Chant, S. and M. C. Gutmann. 2002. Men-streaming gender? Questions for gender and development policy in the twenty-first century. Progress in Gender Studies 2(4): 269-282.

Connell, R. W. 1995. The men and the boys. Berkeley: University of California Press.

Connell, R. W. 2003. The role of men and boys in achieving gender equality. Expert Group Meeting, Brazil, Brasilia 21-24 October.

Connell, R. W. 2005 Change among the gatekeepers: Men, masculinities, and gender equality in the global arena. Signs 30(3): 1801-1825. http://www.jstor.org/stable/10.1086/427525

Cornwall, A. and S. C. White. 2000. Men, masculinities and development: Politics, policies and practice. IDS Bulletin 31(2): 1-6.

Cornwall, A. 2007. Revisiting the gender agenda. IBS Bulletin 38(2): 69-78. https://doi.org/10.1111/j. 1759-5436.2007.tb00353

Diario Oficial de la Federacion. 2007. Ley General de Acceso de las mujeres a una vida libre de violencia. http://www.diutados.gob.mx/LeyesBiblio/pdf/LGAMVLV.pdf (Accessed 12 July 2010). 
ECLAC see Economic Commission for Latin America and the Caribbean.

Economic Commission for Latin America and the Caribbean. n.d. Regional Conference on Women in Latin America and the Caribbean. https:/www.cepal.org/en/subsidiary-bodies/regionalconference-women-latin-america-and-caribbean

Estadistica Institucional Trienio. 2004-2006. Instituto Polítecnico Nacional, Secretaría Técnica Dirección de Evaluación. http://www.gestionestrategica.ipn.mx/Evaluacion/Documents/ Estadistica/ESTADISTICATRIENIO3BCD.PDF

Greig, A., M. Kimmel and J. Lang. 2000. Men, masculinities and development: Broadening our work towards gender equality and development. New York: Gender and Development Programme.

Inmujeres. 2018. Acerca de. https://www.inmujeres.cdmx.gob.mx/instituto/acerca

Kabeer, N. 2001. Conflicts over credit: Re-evaluating the empowerment potential of loans to women in rural Bangladesh. World Development 29: 63-84.

Mohanty, C. T. 1988. "Under western eyes: Feminist scholarship and colonial discourse." Feminist Review 3: 61-88.

Mohanty, C. T. 2003. Feminism without borders: Decolonising theory, practising solidarity. Durham: Duke University Press.

Mohanty, C. T., A. Russo and L. Torres 1991. Third world and the politics of feminism. Bloomington: Indiana University Press.

Moss, D. 2006. Gender, space and time: Women and higher education. Lanham: Lexington Books.

Narayan, D., R. Patel, K. Schaff, A. Rademacher and S. Koch-Schulte. 2000. Can anyone hear us? Voices of the poor. New York: World Bank Publications.

IPN. n.d. Que es el PIGPG. http://www.genero.ipn.mx:70/genero/nuestro_hacer.jsp

Razavi, S. and C. Miller. 1995. From WID to GAD: Conceptual shifts in the women and development discourse. Occasional Paper 1. United Nations Development Program.

Rizvi, F. and B. Lingard. 2010. Globalising education policy. Oxford: Oxford University Press.

Sanchez, A. R. 2003. Escolaridad y trabajo femeninos en el context de la division generic de profesiones y oficios, version actualizada del mismo document publicado por la ENEP Acatlan-UNAM, Mexico.

Sanchez-Cruz, E. 2012. Women in science and engineering: Impact of gender equity policies in Mexican Higher Education. Unpublished $\mathrm{PhD}$ thesis, University of Western Ontario. https://ir.lib. uwo.ca/etd/433.

Sanchez-Cruz, E. and N. Cruz-Cortes. 2015. Mexican gender policies in practice: Two grad students. International Journal of Gender in Developing Societies 1(1): 63-76.

SEP. 2003. Informe Nacional Sobre la Educacion Superior en Mexico.www.anuies.mx/e proyetos/ pdf/Pro_seminario.pdf/ (Accessed 24 November 2010).

Sher, G. 1975. Justifying reverse discrimination in employment. Philosophy and Public Affairs 4(2): 159-170.

Stromquist, N. P. 2015. Reflections on future tasks. Gender and Education 27(2): 109-113.

Tarrés, M. L. 2006. Nuevos nudos y desafíos en las prácticas feministas: Los institutos de las mujeres en México, en N. Lebon y E. Maier (comps.).

Tripathy, J. 2009. The truncated narrative of gender and development. International Journal of Development Issues 8(1): 4-17.

United Nations. 2009. Convention on the elimination of all forms of discrimination against women. http://www.un.org/womenwatch/daw/cedaw

Yeboah, T., R. Serbeh and P. Bembir. 2015. Omission of men in gender development theory and praxis: A pathway for addressing the plights of women. Journal of Social Sciences 11(1): 7-19. 